\title{
Packed Red Blood Cell Transfusion
}

National Cancer Institute

\section{Source}

National Cancer Institute. Packed Red Blood Cell Transfusion. NCI Thesaurus. Code C15409.

The intravenous administration of red blood cells (whole blood without the plasma) into an individual. 